\title{
Application of molecular techniques for the assessment of microorganism diversity on cultural heritage objects*
}

\author{
Anna Otlewska ${ }^{凶}$, Justyna Adamiak and Beata Gutarowska \\ Institute of Fermentation Technology and Microbiology, Faculty of Biotechnology and Food Sciences, Lodz University of Technology, Łódź, \\ Poland
}

\begin{abstract}
As a result of their unpredictable ability to adapt to varying environmental conditions, microorganisms inhabit different types of biological niches on Earth. Owing to the key role of microorganisms in many biogeochemical processes, trends in modern microbiology emphasize the need to know and understand the structure and function of complex microbial communities. This is particularly important if the strategy relates to microbial communities that cause biodeterioration of materials that constitute our cultural heritage. Until recently, the detection and identification of microorganisms inhabiting objects of cultural value was based only on cultivation-dependent methods. In spite of many advantages, these methods provide limited information because they identify only viable organisms capable of growth under standard laboratory conditions. However, in order to carry out proper conservation and renovation, it is necessary to know the complete composition of microbial communities and their activity. This paper presents and characterizes modern techniques such as genetic fingerprinting and clone library construction for the assessment of microbial diversity based on molecular biology. Molecular methods represent a favourable alternative to culturedependent methods and make it possible to assess the biodiversity of microorganisms inhabiting technical materials and cultural heritage objects.
\end{abstract}

Key words: molecular techniques, microbial diversity, metagenomics, genetic fingerprinting, cultural heritage, biodeterioration

Received: 31 October, 2013; revised: 26 March, 2014; accepted: 08 April, 2014; available on-line: 13 June, 2014

\section{INTRODUCTION}

Biosphere is dominated by microorganisms and the total number of microbial cells on Earth is estimated to be approximately $4-6 \times 10^{30}$. As a result of their unpredictable ability to adapt to varying environmental conditions, microorganisms can occur in all biological niches on Earth, from terrestrial environments to the oceans. They play a crucial role in ecological and biogeochemical processes (Simon \& Rolf, 2011).

It is an established knowledge that microorganisms (bacteria, cyanobacteria, archaea and fungi) cause deterioration of various materials, particularly if they are historical objects exposed to changing environmental conditions such as moisture, temperature, $\mathrm{pH}$ and light (Michaelsen et al., 2006). Microorganisms inhabiting historical objects can induce unsightly discoloration of building material and mural paintings, formation of crusts and biofilms, biomineralization and degradation of organic and inorganic materials (De Felice et al., 2010). Their mechanisms of action concern acid and alkali production, alteration of surface properties, heat absorption, increased water retention and direct penetration into the stone structure (Kiel \& Gaylarde, 2006). For the correct restoration and conservation, it is important to detect and identify microbial communities inhabiting historical objects and monuments. Thus, in the first step, major questions have to be asked: (i) what types of microorganisms are present in the sample? (ii) what are the functions of these microorganisms? (iii) how do these microorganisms respond to alternation in environmental conditions? (iv) what is the relationship between functions of microorganisms and their environment? Answers to these key questions allow us to understand the structure and function of complex microbial communities, and, as a result, choose appropriate strategies for restoration and maintenance of cultural heritage objects (Handelsman, 2004). Therefore, the biodiversity analysis of microbial communities colonizing cultural heritage objects is based on a number of techniques such as microscopy, culture methods and biochemical tests.

For a long time, culture-dependent methods have been used to detect and identify microorganisms inhabiting historical buildings and monuments. Culture-based approaches are a powerful tool for understanding the physiological and biochemical potential of isolated organisms, however they do not provide information on the diversity of complex microbial communities. This is due to the fact that only $0.1-1 \%$ of microorganisms present in the natural environment can be assessed by using conventional culture-dependent methods that allow isolation of only viable and culturable organisms under standard laboratory conditions (Schabereiter-Gurtner et al., 2001). A vast majority of metabolically active strains (approximately 99\%) occurs in the environment in the state of anabiosis, being viable but non-culturable (VBNC). Non-culturable microorganisms fall into one

e-mail: anna.otlewska@p.lodz.pl

* The preliminary report on the same subject was presented at MIKROBIOT 2013 Workshop, Łódź, Poland

Abbreviations: ARDRA, amplified rDNA restriction analysis; ARISA, automated ribosomal intergenic spacer analysis; ATP, adenosine triphosphate; BAC, bacterial artificial chromosome; BLAST, basic local alignment search tool; ddNTP, dideoxynucleotides; DGGE, denaturing gradient gel electrophoresis; IGS, intergenic spacer region; ITS, internal transcribed spacer; NCBI, National Center for Biotechnology Information; PCR, polymerase chain reaction; $\mathrm{PPi}$, pyrophosphate molecule; SSCP, single strand conformation polymorphism; T-RFLP, terminal restriction fragment length polymorphism; TGGE temperature gradient gel electrophoresis; VBNC, viable but nonculturable. 
of the three groups: (i) obligate symbiotic and parasitic organisms unable to grow on microbiological media; (ii) known species, in the identification of which culture-dependent methods prove to be inadequate; (iii) unknown species that have never been grown before, due to the lack of appropriate methods (Ripka et al., 2006).

The VBNC state can be attained in the aging process and it may also be caused under conditions of environmental stress. Additionally, in the case of poorly known microorganisms, it is necessary to provide specific nutritional requirements, which is often associated with problems in defining the composition of the culture medium. Culture media used to isolate environmental microbes include saccharides, proteins and vitamins in concentrations which have never occurred under environmental conditions. They enable the development of fast-growing species and production of valuable metabolites, and shorten the incubation time, but on the other hand, they hinder the development of microorganisms in the ecosystem. Difficulties in isolation of such organisms represent a significant reduction in a biodiversity analysis of complex ecosystems, such as historical buildings. Therefore, several authors have proposed solutions involving culture-independent techniques to solve the problem of detecting and identifying these types of microorganisms in the natural environment (Gonzalez \& Saiz-Jimenez, 2005)

Since the majority of microorganisms in natural samples cannot be cultured according to standard procedures and the culture-dependent methods provide only limited information on the biodiversity of microorganisms thriving on cultural heritage objects, molecular methods are essential tools for analysing microbial communities (Gonzalez et al., 2003).

Recently, increasing attention is paid to a new field of science - metagenomics, which over the past decade has revolutionized biological sciences, including microbiology. The term metagenomics was used in scientific literature for the first time by Handelsman in 1998 and it referred to a study of a complex microbial population at the molecular level (Deja-Sikora et al., 2007). At present, the term metagenomics refers to a study of genetic material isolated directly from an environmental sample, whereby it is possible to analyse all of the microorganisms from the sample, including the non-culturable ones.

This paper describes current molecular techniques that are applied in biodiversity studies of microbial communities on cultural heritage objects.

\section{MOLECULAR DETECTION OF MICROORGANISMS}

\section{Isolation of nucleic acids and amplification of target genes}

Extraction of nucleic acids from a sample is often the first step in the detection and identification of microorganisms in complex ecosystems by using molecular analysis. However, small amount of material for analysis (less than $1 \mathrm{mg}$ ) is a major problem in the identification of microorganisms responsible for the biodeterioration of historical objects in particular. In addition, numerous sample contaminants greatly hinder analysis and delivery of reliable results (Ripka et al., 2006). Therefore, most molecular strategies are based on PCR-amplification of specific target genes (rRNA genes) in order to obtain a large number of copies of DNA fragments (Gonzalez \& Saiz-Jimenez, 2005). The most common molecular markers used for identification are genes that encode small

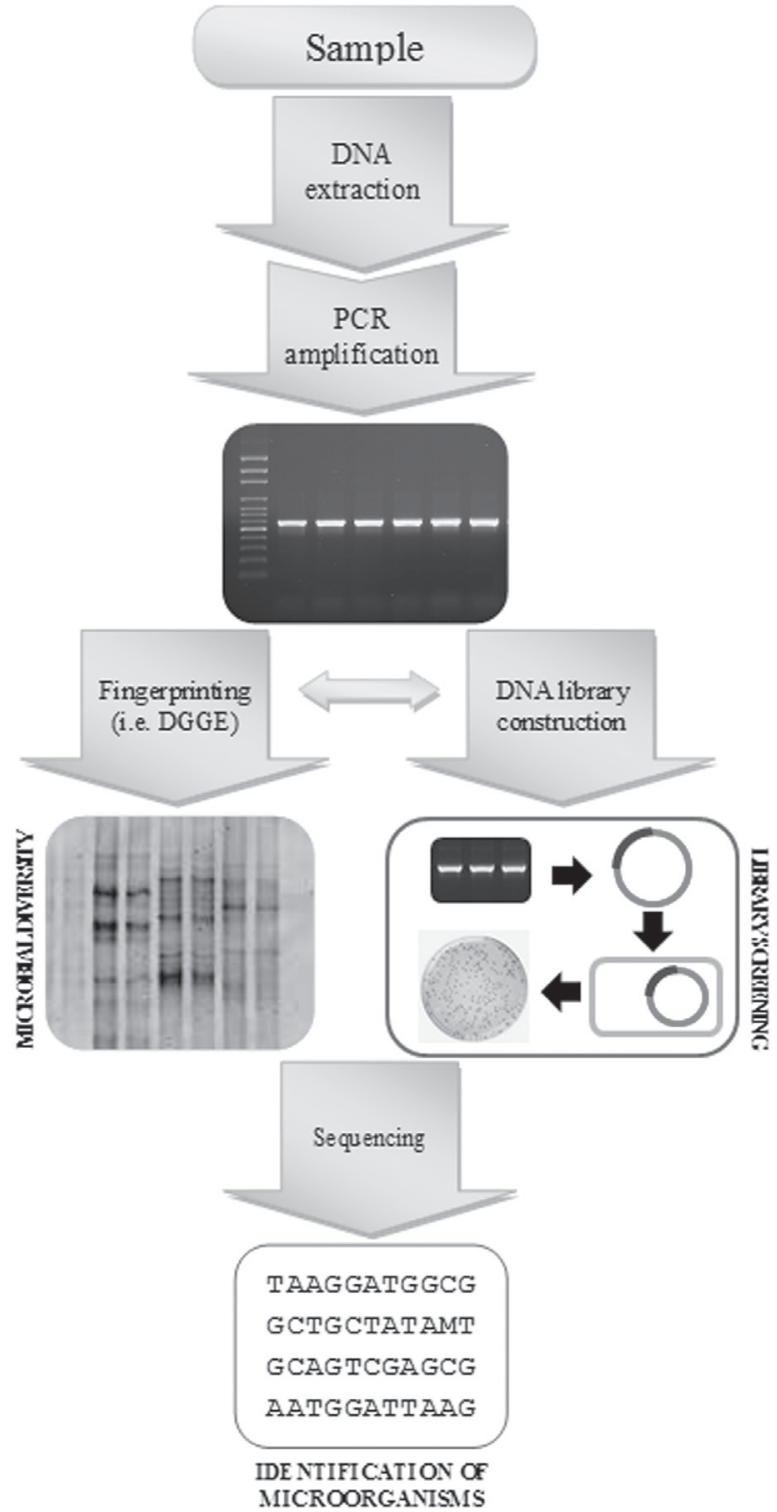

Figure 1. General scheme of the molecular approach in the analysis of microbial community structure.

subunit ribosomal RNA (rRNA): 16S rRNA for prokaryotes and 18S rRNA for eukaryotes (Gonzalez \& SaizJimenez, 2005; Dakal \& Arora, 2012). These genes are considered to be the gold standard and have been used extensively in molecular detection and identification of microorganisms in environmental samples, because: (i) they are ubiquitous in all prokaryotic and eukaryotic organisms; (ii) they are structurally and functionally conserved; and (iii) they possess both, highly conserved and variable regions (Rastogi \& Sani, 2011). Based on analyses of these rRNA genes, cellular life has been classified into three primary domains: one eukaryotic (Eukarya) and two prokaryotic (Bacteria and Archaea) (Rastogi \& Sani, 2011). The 16S rRNA gene contains nine hyper-variable regions flanked by relatively conserved regions in the primary and secondary structures (Shah et al., 2011; Neelakanta \& Sultana, 2013).

An analysis of nucleotide sequences of the $16 \mathrm{~S}$ rRNA genes allowed the detection and identification of bacteria present in mural paintings in St Martin's Church in Germany (Gurtner et al., 2000; Gorbushina et al., 2004), 
Saint Catherine Chapel of Castle Herberstein in Austria (Gurtner et al., 2000), Crypt of the Original Sin in Italy (Nugari et al., 2009), Santissima Annuziata in Italy (Milanesi et al., 2006), and those forming a biofilm on the surface of stones from the Catacombs of St Callixtus in Italy (De Leo et al., 2012), Necroplis at Tarquinia in Italy (Alisi et al., 2011), Roman Necropolis at Carmona in Spain (Smerda et al., 2006) and the Egyptian Tombs in the East Nile Delta in Egypt (Abdel-Haliem et al., 2013).

Molecular marker most commonly used for the identification of molds is internal transcribed spacer (ITS) region located between $18 \mathrm{~S}$ and $28 \mathrm{~S}$ rRNA which consists of internal non-coding regions ITS1, ITS2 and 5.8S rRNA gene. This region comprises both, highly conserved regions (5.8S), showing similarity even between evolutionarily distant organisms and sequences with high genetic variability (ITS regions), so they can be successfully used in determining genera and species. In addition, the ITS regions are of particular importance in molecular diagnostics of molds, because they are present in all fungi in a large number of copies, which increases the sensitivity and specificity of the PCR reaction (Ciardo et al., 2007, 2010; Atkins \& Clark, 2004).

PCR products amplified from environmental DNA can be analysed by (i) genetic fingerprinting, (ii) clone library methods, or (iii) by combination of these techniques (Fig. 1) (Rastogi \& Sani, 2011).

\section{CLONE LIBRARY CONSTRUCTION METHOD}

Construction of a clone library is the most widely used method to analyse PCR products (such as $16 \mathrm{~S}$ or $18 \mathrm{~S}$ rRNA genes) amplified from an environmental sample. A metagenomic analysis of a microbial community by constructing gene libraries includes: (i) isolation of metagenomic DNA; (ii) fragmentation and insertion of DNA into appropriate vectors; (iii) DNA cloning and transformation into suitable host cells; iv) screening of the clone library, and (v) bioinformatics analysis (Mocali \& Benedetti, 2010). An important step in the construction of DNA libraries is the choice of suitable vectors and host strains. In the construction of gene library, it is better to use large fragments to minimize the number of clones. When DNA is to be amplified by PCR, greater attention is paid to DNA yield, rather than size (Miller et al., 1999; Mocali \& Benedetti, 2010). Thus, clone libraries can be distinguished and qualified based on size: bacterial plasmids (if the insert is less than $20 \mathrm{~kb}$ ), cosmids and fosmids (if the insert size ranges from 25 to $35 \mathrm{~kb}$ ) or bacterial artificial chromosome (BAC) vectors (if the insert is more than $40 \mathrm{~kb}$ ). Another important part of constructing gene libraries is the selection of a suitable host strain. Escherichia coli is the most preferred host for cloning and expression of any metagenome-derived genes. However, recently, other host strains such as Streptomyces lividans, Rhizobium leguminosarum and Pseudomonas aeruginosa have been also used for the detection of bioactive compounds (Streit \& Schmitz, 2004; Mocali \& Benedetti, 2010).

Analysis of metagenomic libraries can be performed by identification of clones having a desired function or carrying a specific sequence. The first approach relates to genes encoding enzymes or metabolites and does not require sequencing. The second approach allows specification of biodiversity by $16 \mathrm{~S}$ rRNA gene analysis by using bioinformatic tools and involves screening of the derived clones and then their sequencing (Deja-Sikora et al., 2007; Mocalli \& Benedetti, 2010). Screening of $16 \mathrm{~S}$
rRNA library is a costly and time-consuming process. Therefore, in order to simplify and shorten these procedures, standard screening strategies rely on an analysis of a number of clones with the use of molecular fingerprinting methods (Gonzalez et al., 2003).

A metagenomic analysis based on construction of gene libraries was successfully used in the identification of microorganisms (bacteria, cyanobacteria, fungi) inhabiting artistic tiles from Pena National Palace in Sintra, Portugal. PCR products were cloned into TOPO vector and clone representatives were sequenced to determine their phylogenetic affiliations. Then, the obtained sequences were clustered into operational taxonomic units (Coutinho et al., 2013). Construction of 16S rRNA gene library strategy was also applied in the analysis of biodiversity of epilithic and endolithic bacterial communities in limestone from a Maya archaeological site. In this case, gene library was also constructed based on TOPO vector. Nucleotide sequences from the clones thus obtained were compared to the GenBank database using BLAST (McNamara et al., 2006).

\section{FINGERPRINTING TECHNIQUES AND THEIR APPLICATION IN BIODETERIORATION STUDIES}

Genetic fingerprinting includes techniques based on electrophoretic analysis of PCR products amplified from metagenomic DNA. Currently, there are several molecular biology methods used to obtain microbial fingerprints from environmental samples: DGGE/TGGE (denaturing/temperature gradient gel electrophoresis), SSCP (single strand conformation polymorphism), ARDRA (amplified rDNA restriction analysis), T-RFLP (terminal restriction fragment length polymorphism), and ARISA (automated ribosomal intergenic spacer analysis). In addition to the detection of microbial cells, fingerprinting approaches also allow for the determination of profiles of quantitative changes in the composition of an ecosystem, but they do not provide direct taxonomic identifications (Table 1) (Rastogi \& Sani, 2011). Genetic fingerprinting is a rapid and useful method for studying diversity in microbial communities, including non-culturable and inactive microorganisms (Gurtner et al., 2000; Gonzalez \& Saiz-Jimenez, 2005; Dakal \& Arora, 2012).

Procedure starts with DNA isolation, then a gene is amplified (16S rRNA, 18S rRNA, 23S rRNA, IGS region), and in the final stage, the PCR product is analysed by electrophoresis in an agarose or polyacrylamide gel. This leads to the so-called fingerprint, i.e. a characteristic pattern of bands, compared with databases in the course of further research (Muyzer, 1999; Rastogi \& Sani, 2011).

\section{Denaturing or temperature gradient gel electrophoresis}

Denaturing or temperature gradient gel electrophoresis are molecular techniques most commonly used in studies of microorganisms associated with biodeterioration of monuments and artworks (Schabereiter-Gurtner et al., 2001; Ripka et al., 2006; Gaylarde et al., 2012).

In denaturing gradient gel electrophoresis (DGGE), the PCR-amplified molecular markers (16S rRNA or $18 \mathrm{~S}$ rRNA genes) are separated in polyacrylamide gels containing a linearly increasing gradient of denaturants such as urea and formamide. In these methods, DNA fragments of equal length, but with different base-pair sequences can be separated (Muyzer et al., 1993; Muyzer \& Smalla, 1998). Temperature gradient gel electrophoresis (TGGE) relies on the same principle as DGGE, except that temperature gradient 


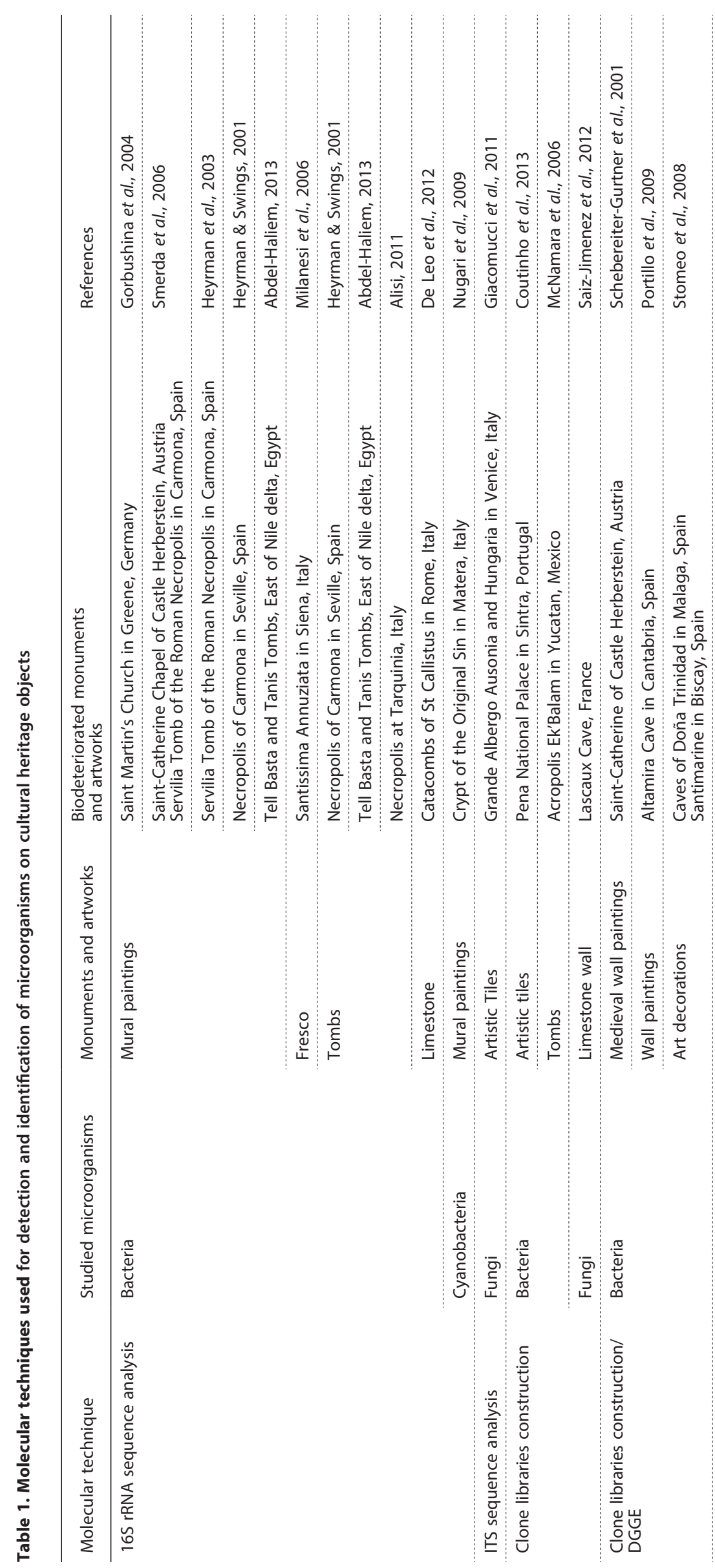




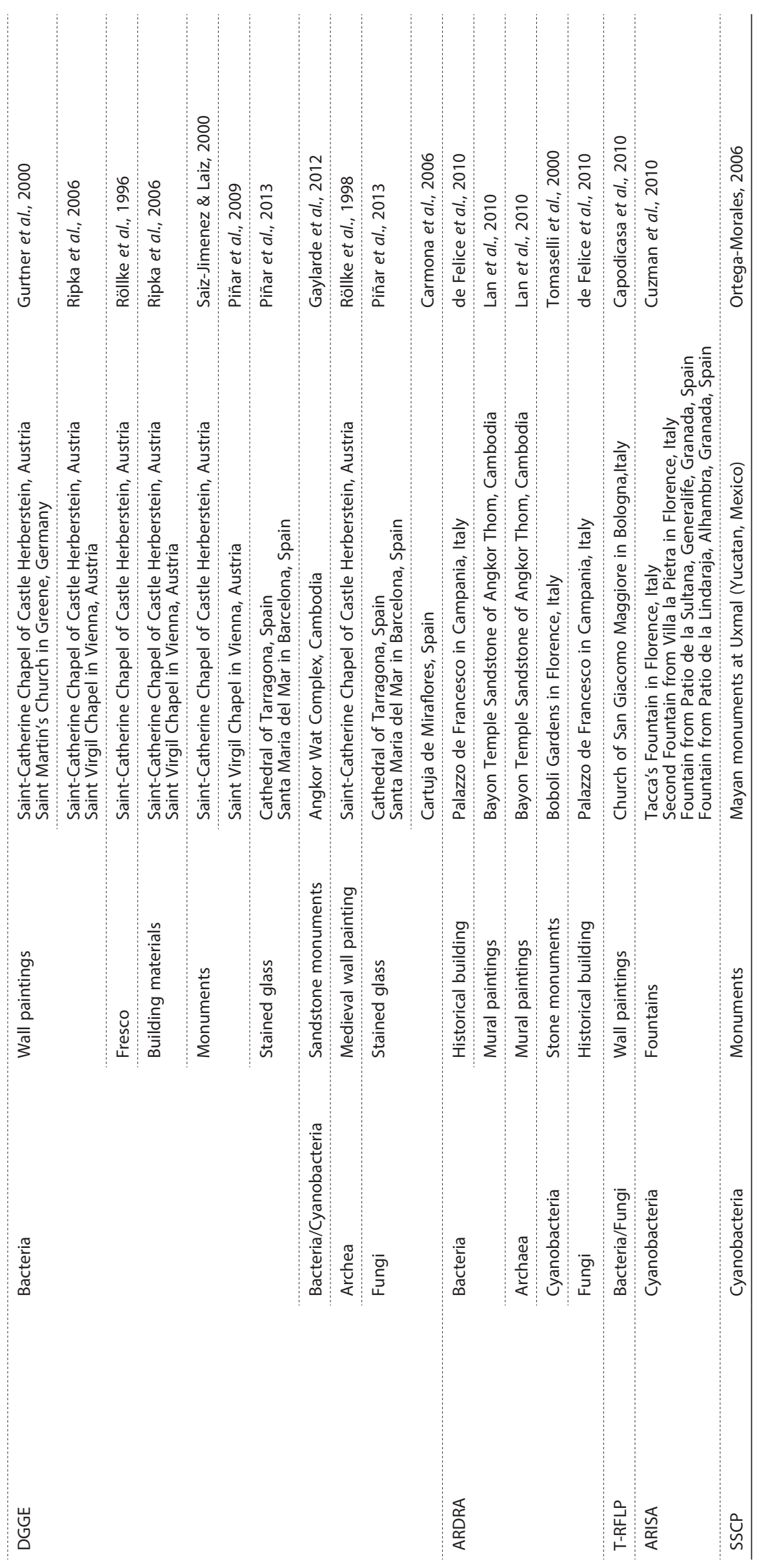


is used instead of a mixture of urea and formamide (Rastogi \& Sani, 2011). Migration of DNA fragments in DGGE and TGGE is based on the electrophoretic mobility of a partially melted DNA molecule in the polyacrylamide gel. Melting of the double-stranded DNA occurs in domains and is depended on the nucleotide sequence. When the melting domain with the lowest melting temperature reaches a particular position in the polyacrylamide gel, a transition of helical to partially melted molecule occurs, and the molecule practically stops migrating at different positions in the gel. Differences in the nucleotide sequences of the DNA fragments studied determine differences in melting temperatures of particular domains within a fragment, and thus a difference in the migration distance of DNA molecules during electrophoretic separation (Muyzer et al., 1993; Muyzer \& Smalla, 1998; Muyzer, 1999; Wiecckowicz, 2009). The DGGE or TGGE techniques allow the detection of approximately $50 \%$ of differences in sequence of fragments up to $500 \mathrm{bp}$. By using GC-tailed (30-50 bp) primers, this percentage can be increased to approximately $100 \%$. The GC-clamp facilitates stabilization of migration of the DNA fragments during denaturing or temperature gradient gel electrophoresis (Muyzer \& Smalla, 1998). The main advantage of this fingerprinting strategy is that bands can be excised from the polyacrylamide gel, re-amplified and sequenced to reveal the phylogenetic affiliation of a community member. However, the main limitation of this method is that it separates only relatively short fragments of up to $500 \mathrm{bp}$, which may cause difficulty in interpreting results. Here, significant problems include too many DNA fragments and similar melting points for different DNA fragments (Muyzer \& Smalla, 1998; Rastogi \& Sani, 2011).

The DGGE/TGGE techniques have been applied to evaluate the structure of microbial communities consisting of bacteria (Rölleke et al., 1996; Gurtner et al., 2000; Schabereiter-Gurtner et al., 2001; Gorbushina et al., 2004; Ripka et al., 2006; Piñar et al., 2009, 2013; Gaylarde et al., 2012), cyanobacteria (Cappitelli et al., 2009; Gaylarde et al., 2012), archaea (Rölleke et al., 1998; Piñar et al., 2001a,b) and fungi (Carmona et al., 2006; SchabereiterGurtner et al., 2001; Giacomucci et al., 2011). Several authors have used these methods to study the biodeterioration of wall paintings (Rölleke et al., 1996, 1998; Gurtner et al., 2000; Schabereiter-Gurtner et al., 2001; Gorbushina et al., 2002; Ripka et al., 2006), prehistoric cave paintings (Schabereiter-Gurtner et al., 2001), stained window glasses (Carmona et al., 2006; Piñar et al., 2013), and monuments (Saiz-Jimenez \& Laiz, 2000; Piñar et al., 2009; Gaylarde et al., 2012).

\section{Amplified ribosomal RNA restriction analysis}

Amplified ribosomal RNA restriction analysis (ARDRA) is based on a principle that the recognition site of restriction enzymes is different for different microbial species (Cetecioglu et al., 2012). In the first step, ribosomal RNA genes (16S rRNA or $18 \mathrm{~S} \mathrm{rRNA}$ ) are amplified by PCR from environmental DNA as a template. PCR products are digested into specific DNA fragments with tetracutter restriction endonucleases. Restriction fragments are then separated on agarose or polyacrylamide gels (Rastogi \& Sani, 2011; Sklarz et al., 2011; Cetecioglu et al., 2012). ARDRA is a useful method for rapid monitoring of microbial communities over time, or comparing biodiversity in response to changing environmental conditions. Sometimes it is not possible to separate the restriction profiles obtained from microbial communities by agarose or polyacrylamide electrophoresis (Rastogi \& Sani, 2011). One of the major limitations of ARDRA is that it provides little or no information about the type of microorganisms present in the sample (Gich et al., 2000). The ARDRA method was used to evaluate the biodiversity of cyanobacteria on stone monuments in the Boboli Gardens in Florence (Tomaselli et al., 2000). In the detection of microorganisms forming a biofilm on Bayon temple sandstone of Angkor Thom, Cambodia (Lan et al., 2010) and those causing discolouration of the walls of Palazzo De Francesco in Campania, Italy (De Felice et al., 2010) the ARDRA technique was used in the screening of $16 \mathrm{~S}$ and $18 \mathrm{~S}$ rRNA clones library with appropriate restriction enzymes (e.i. RsaI, MspI). Following this, the clones showing identical restriction profiles were grouped into operational taxonomic units (OTUs). Moreover, clones representing each distinct ARDRA pattern were sequenced, which further allowed for the identification of microorganisms.

\section{Terminal restriction fragment length polymorphism}

Terminal restriction fragment length polymorphism (T-RFLP) is often used to supplement the ARDRA technique. Similarly, as in the case of amplified ribosomal RNA restriction analysis, the T-RFLP protocol involves amplification of the 16S rRNA gene by using the PCR method. The major difference from ARDRA is that one or both primers used during the PCR reaction are 5'-fluorescently labelled (Liu et al., 1997; Więckowicz, 2009). Amplified target genes are digested with restriction enzymes and the obtained terminal restriction fragments (TRFs) are separated by using capillary or polyacrylamide gel electrophoresis in an automated DNA sequencer. Only the terminally fluorescently labelled restriction fragments are detected, which greatly simplifies restriction profiles and allows the analysis of the structure of microbial communities (Muyzer, 1999; Rastogi \& Sani, 2011; Cetecioglu et al., 2012). Biodiversity of a microbial community is estimated by analysing the number, size, and peak's height of resulting terminal restriction fragments (Rastogi \& Sani, 2011). To determine the qualitative structure of the microbial population, the resulting image is compared with specially configured databases. Owing to the technique, it was possible to differentiate very closely related microorganisms present on mural paintings in Church of San Giacomo Maggiore in Bologna (Capodicasa et al., 2010).

\section{Single strand conformation polymorphism}

Single strand conformation polymorphism (SSCP) is based on separation of the same-length DNA fragments according to their differences in mobility in polyacrylamide gel caused by differences in the secondary structure of folded DNA. PCR products are denatured and this is followed by electrophoretic separation in a non-denaturing polyacrylamide gel (Cetecioglu et al., 2012). The SSCP method does not require GC clamped primers and gradient gel. Therefore, compared to other fingerprinting methods, this technique is simple and straightforward (Rastogi \& Sani, 2011). One of the disadvantages of SSCP is separation of only small DNA fragments ranging from 150 to $400 \mathrm{bp}$. Moreover, a single-strand DNA sequence can form more than one stable conformation and this fragment can be represented by multiple bands (Rastogi \& Sani, 2011; Cetecioglu et al., 2012). 


\section{Automated ribosomal intergenic spacer analysis}

Automated ribosomal intergenic spacer analysis (ARI$\mathrm{SA}$ ) is a high resolution, culture-independent method suitable for an analysis of biodiversity and richness of microbial communities. Developed by Fisher and Triplett (1999), the PCR fingerprinting technique is based on the size and nucleotide sequence variability of the intergenic spacer region (IGS) present between the small (16S) and large (23S) ribosomal subunits (Cardinale et al., 2004; Popa et al., 2009). The IGS fragments are analysed by an automated capillary electrophoresis system containing a laser detector. The main limitation of ARISA is a large number of peaks in the case of using "universal primers". In addition, it is very difficult to interpret results for fingerprints obtained for uncultured microorganisms (Popa et al., 2009). The ARISA technique was applied by Cuzman and coworkers (2010) to study the species structure of biofilms formed in historic fountains in Italy and Spain.

\section{DNA SEQUENCING}

Sequence of nucleotides in nucleic acid molecules is determined by sequencing which is the most accurate method for determining the identity of a PCR product. The Sanger's method, also referred to as the chain termination method, is the most common. The starting material in this technique includes identical single-stranded DNA molecules, suitable primers and hydroxyl groupfree dideoxynucleotides (ddNTP), which means that after being incorporated into the synthesized strand, they prevent its further extension. In this method, DNA fragments obtained are of different lengths, and they are separated by electrophoresis, while bands corresponding to individual products of termination are displayed by radiography (Mecler \& Nawrot, 2007; Raszka et al., 2009).

Currently, there are several methods to increase the efficiency of sequencing that are much faster and less expensive than Sanger's technique. The next-generation DNA sequencing techniques (NGS) have revolutionized microbial ecology and genomics, and allow to investigate phylogenetic composition and functional diversity of environmental microbial communities (Rastogi \& Sani, 2011). Pyrosequencing is one of the next-generation DNA sequencing techniques based on the detection of a pyrophosphate molecule (PPi) released during the DNA synthesis. dNTPs added sequentially trigger a cascade of enzymatic reactions, resulting in light emission, the intensity of which depends on the amount of released pyrophosphate. In the first stage, polymerization of nucleic acid occurs, resulting in the release of PPi. This compound is then converted to ATP by the action of the sulfurylase enzyme. The energy obtained in this way is used in the next step - oxidation of luciferin in a reaction catalysed by the luciferase enzyme, which is accompanied by light emission. Tracking which of the dNTPs was added allows determination of the template sequence (Mecler \& Nawrot, 2007; Ronaghi, 2013).

\section{BIOINFORMATIC TOOLS AND DATABASES USED IN METAGENOMICS}

From the point of view of detection and identification of microorganisms inhabiting museum objects, nucleotide databases play a key role. Determination of a sequence homology between an investigated product and thousands of sequences collected in public (National
Center for Biotechnology Information NCBI, GenBank), or commercial databases is possible by using suitable computer programs, such as BLAST which is among the most widely used ones (Mecler \& Nawrot, 2007). The BLAST algorithm is a heuristic program which performs "local" alignments, based on shortcuts, and its task is to conduct a quick search (Tatusova \& Madden, 1999).

\section{FUTURE PERSPECTIVES}

During the last decades, strategies to evaluate biodeterioration of historical objects have adopted many molecular biology techniques developed from other sciences, in particular microbial ecology and clinical analyses, for the detection of microorganisms. Despite the fact that the continuous improvement of various genetic and bioinformatic tools enables precise determination of not only the structure of microbial populations present in complex ecosystems in an ever shorter time, but also the roles of microbes in the environment, it is still impossible to avoid many of the difficulties in the analyses. However, the unquestionable advantage of applying molecular methods in the studies of microbial communities is that they enable the detection and identification of viable but non-culturable microorganisms, especially if we look for causes and microorganisms potentially responsible for biodeterioration of valuable historical objects for the sake of their proper maintenance and protection. However, one should not forget about the culture-dependent methods that despite many limitations are still required to study the physiology and metabolism of microorganisms. The molecular methods described herein are only a small section of the techniques used in the biodiversity analysis of microorganisms inhabiting objects of historical significance.

\section{REFERENCES}

Abdel-Haliem MEF, Sakr AA, Ali MF, Ghaly MF, Sohlenkamp C (2013) Characterization of Streptomyces isolates causing colour changes of mural paintings in ancient Egyptian tombs. Microbiol Res 168: 428-437.

Alisi C (2011) Biodegradation and biorestoration of stone manufacts. Letture di Georisorse e Ambiente 3: 94-109.

Atkins SD, Clark IM (2004) Fungal molecular diagnostic: a mini review. I Appl Genet 45: 3-15.

Cappitelli F, Abbruscato P, Foladori P, Zanardini E, Ranalli G, Principi P, Villa F, Polo A, Sorlini C (2009) Detection and elimination of cyanobacteria from frescoes: the case of the St. Brizio Chapel (Orvieto Cathedral, Italy). Microb Ecol 57: 633-639.

Capodicasa S, Fedi S, Porcelli AM, Zannoni D (2010) The microbial community dwelling on a biodeteriorated 16 th century painting. Int Biodeter Biodegr 64: 727-733.

Cardinale M, Brusetti L, Quatrini P, Borin S, Puglia AM, Rizzi A, Zanardini E, Sorlini C, Corselli C, Daffonchio D (2004) Comparison of different primer sets for use in automated ribosomal intergenic spacer analysis of complex bacterial communities. Appl Environ Microbiol 70: 6147-6156.

Carmona N, Laiz L, Gonzalez JM, Garcia-Heras M, Villegas MA, SaizJimenez C (2006) Biodeterioration of historic stained glasses from the Cartuja de Miraflores (Spain). Int Biodeter Biodegr 58: 155-161.

Cetecioglu Z, Ince O, Ince B (2012) Gel electrophoresis based genetic fingerprinting techniques on environmental ecology. In Gel electrophoresis - advanced techniques. Magdeldin S, eds, pp 52-66. InTech, Croatia.

Ciadro DE, Lucke K, Imhof A, Bloemberg GV, Bottger EC (2010) Systematic internal transcribed spacer sequence analysis for identification of clinical mold isolates in diagnostic mycology: a 5-year study. J Clin Microbiol 48: 2809-2813.

Ciardo DE, Schär G, Altwegg M, Böttger EC, Bosshard PP (2007) Identification of moulds in the diagnostic laboratory - an algorithm implementing molecular and phenotypic methods. Diagn $\mathrm{Mi}$ crobiol Infect Dis 59: 49-60.

Coutinho ML, Miller AZ, Gutierrez-Patricio S, Hernandez-Marine M, Gomez-Bolea A, Rogerio-Candelera MA, Philips AJL, Jurado V, 
Saiz-Jimenez C, Macedo MF (2013) Microbial communities on deteriorated artistic tiles from Pena National Palace (Sintra, Portugal). Int Biodeter Biodegr 84: 322-332.

Cuzman OA, Ventura S, Sili C, Mascalchi C, Turchetti T, D’Acqui LP, Tiano P (2010) Biodiversity of phototrophic biofilms dwelling on monumental fountains. Microb Ecol 60: 81-95.

Dakal TC, Arora PK (2012) Evaluation of potential of molecular and physical techniques in studying biodeterioration. Rev Environ Sci Biotechnol 11: 71-104.

De Felice B, Pasquale V, Tancredi N, Scherillo S, Guida M (2010) Genetic fingerprint of microorganisms associated with the deterioration of an historical tuff monument in Italy. J Genet 89: 253-257.

Deja-Sikora E, Sikora M, Gołębiewski M, Tretyn A (2007) Biblioteki metagenomowe jako źródło genów przydatnych w biotechnologii. Biotechnologia 4: 125-139 (in Polish).

De Leo F, Iero A, Zammit G, Urzi CE (2012) Chemoorganotrophic bacteria isolated from biodeteriorated surfaces in cave and catacombs. Int J Speleol 41: 125-136.

Fisher MM, Triplet EW (1999). Automated approach for ribosomal intergenic spacer analysis of microbial diversity and its application to freshwater bacterial communities. Appl Environ Microbiol 65: 46304636.

Gaylarde CC, Rodriguez CH, Navarro-Noya YE, Ortega-Morales BO (2012) Microbial biofims on the sandstone monuments of the Angkor Wat Complex, Cambodia. Curr Microbiol 64: 85-92.

Giacomucci L, Bertoncello R, Salvadori O, Martini I, Favaro M, Villa F, Sorlini C, Cappitelli F (2011) Microbial deterioration of artistic tiles from the façade of the Grande Albergo Ausonia and Hungaria (Venice, Italy). Microb Ecol 62: 287-298.

Gich FB, Amer E, Figueras JB, Abella CA, Balaguer MD, Poch M (2000) Assessment of microbial community structure changes by amplified ribosomal DNA restriction analysis (ARDRA). Int Microbiol 3: 103-106.

Gonzalez JM, Ortiz-Martinez A, Gonzalez-del Valle MA, Laiz L, SaizJimenez C (2003) An efficient strategy for screening large cloned libraries of amplified 16S rRNA sequences from complex environmental communities. J Microbiol Methods 55: 459-463.

Gonzalez JM, Saiz-Jimenez C (2005) Unknown microbial communities on rock art painting. Consequences for conservation and future perspectives. Coalition 10: 4-7.

Gorbushina AA, Heyrman J, Dornieden T, Gonzalez-Delvalle M, Krumbein WM, Laiz L, Petersen K, Saiz-Jimenez C, Swings J (2004) Bacterial and fungal diversity and biodeterioration problems in mural painting environments of St. Martins church (Greene-Kreiensen, Germany). Int Biodeter Biodegr 53: 13-24.

Gorbushina AA, Lialikova NN, Vlasov DI, Khizhniak TV (2002) Microbial communities on the monuments of Moscow and St. Petersburg: biodiversity and trophic relations. Mikrobiologiia 71: 409-417.

Gurtner C, Heyrman J, Piñar G, Lubitz W, Swings J, Rölleke S (2000) Comparative analyses of the bacterial diversity on two different biodeteriorated wall paintings by DGGE and $16 \mathrm{~S}$ rDNA sequence analysis. Int Biodeter Biodegr 46: 229-239.

Handelsman J (2004) Metagenomics: application of genomics to uncultured microorganisms. Microbiol Mol Biol Rev 68: 669-685.

Heyrman J, Swings J (2001) 16S rDNA sequence analysis of bacterial isolates from biodeteriorated mural paintings in the Servilia Tomb (Necropolis of Carmona, Seville, Spain). Appl Microbiol 24: 417-422.

Heyrman J, Balcaen AN, Rodriguez-Diaz M, Logan AN, Swings J, De Vos P (2003) Bacillus decolorationis sp. nov., isolated from biodeteriorated parts of the mural paintings at the Servilia tomb (Roman necropolis of Carmona Spain) and the Saint-Catherine chapel (Castle Herberstein, Austria). Int J Sys Evol 53: 459-463.

Kiel G, Gaylarde CC (2006) Bacterial diversity in biofilms on external surfaces of historic buildings in Porto Alegre. World J Microb Biot 22: 293-297.

Lan W, Li H, Wang WD, Katayama Y, Gu JD (2010) Microbial community analysis of fresh and old microbial biofilms on Bayon temple sandstone of Angkor Thom, Cambodia. Microb Ecol 60: 105-115.

Liu WT, Marsh TL, Cheung H, Forney LJ (1997) Characterization of microbial diversity by determining terminal restriction fragment length polymorphisms of genes encoding 16S rRNA. Appl Environ Microbiol 63: 4516-4522.

McNamara CJ, Perry TD, Bearce KA, Hernandez-Duque G, Mitchell R (2006) Epilithic and endolithic bacterial communities in limestone from a Maya Archaeological Site. Microb Ecol 51: 51-64.

Mecler I, Nawrot U (2007) Techniki molekularne stosowane w diagnostyce mikrobiologicznej. Mikol Lek 14: 280-284 (in Polish).

Michaelsen A, Pinzari F, Ripka K, Lubitz W, Piñar G (2006) Application of molecular techniques for identification of fungal communities colonizing paper material. Int Biodeter Biodegr 58: 133-141.

Milanesi C, Baldi F, Borin S, Vignani R, Ciampolini F, Faleri C, Cresti M (2006) Biodeterioration of fresco by biofilm forming bacteria. Int Biodeter Biodegr 57: 168-173.

Miller DN, Bryant JE, Madsen EL, Ghiorse WC (1999) Evaluation and optimization of DNA extraction and purification procedures for soil and sediment samples. Appl Environ Microbiol 65: 4715-4724.
Mocali S, Benedetti A (2010) Exploring research frontiers in microbiology: the challenge of metagenomics in soil microbiology. Res $\mathrm{Mi}$ crobiol 161: 497-505.

Muyzer G (1999) DGGE/TGGE a method for identifying genes from natural ecosystems. Curr Opin Microbiol 2: 317-322.

Muyzer G, de Wall EC, Uitterlinden AG (1993) Profiling of complex microbial populations by denaturing gradient gel electrophoresis analysis of polymerase chain reaction — amplified genes coding for 16S rRNA. Appl Environ Microbiol 59: 695-700.

Muyzer G, Smalla K (1998) Application of denaturing gradient gel electrophoresis (DGGE) and temperature gradient gel electrophoresis (TGGE) in microbial ecology. Anton Leeum 73: 127-141.

Neelakanta G, Sultana H (2013) The use of metagenomic approaches to analyze changes in microbial communities. Microbiol Insights 6: $37-48$.

Nugari MP, Pietrini AM, Caneva G, Imperi F, Visca P (2009) Biodeterioration of mural paintings in a rocky habitat: The Crypt of the Original Sin (Matera, Italy). Int Biodeter Biodegr 63: 705-711.

Ortega-Morales BO (2006) Cyanobacterial diversity and ecology on historic monuments in Latin America. Rev Latinoam Microbiol 48: 188-195.

Piñar G, Gurtner C, Lubitz W, Rölleke S (2001a) Identification of archaea in objects of art by denaturing gradient gel electrophoresis analysis and shotgun cloning. Methods Ensymol 336: 356-366.

Piñar G, Gurtner C, Ramos C, Lubitz W, Rölleke S (2001b) Identification of archaea in deteriorated ancient wall paintings by DGGE and FISH analysis. In Protection and conservation of the cultural heritage of the Mediterranean cities. Galan E, Zezza E, eds, pp 209-214. Balkema/ Swets and Zeitlinger.

Piñar G, Ripka K, Weber J, Sterflinger K (2009) The microbiota of a subsurface monument the medieval chapel of St. Virgil (Vienna, Austria). Int Biodeter Biodegr 63: 851-859.

Piñar G, Garcia-Valles M, Gimento-Torrente D, Fernandez-Turiel JL, Ettenauer J, Sterflinger K (2013) Microscopic, chemical and molecular - biological investigation of the decayed medieval stained window glasses of two Catalonian churches. Int Biodeter Biodegr 84: 388-400.

Popa R, Mashall MJ, Nguyen H, Tebo BM, Brauer S (2009) Limitations and benefits of ARISA intra-genomic diversity fingerprinting. J Microbiol Methods 78: 111-118.

Portillo MC, Saiz-Jimenez C, Gonzalez JM (2009) Molecular characterization of total and metabolically active bacterial communities of "white colonizations" in the Altamira Cave, Spain. Res Microbiol 160: 41-47.

Rastogi G, Sani RS (2011) Molecular techniques to asses microbial community structure, function and dynamics in the environment. In Microbes and microbial technology: agricultural and environmental applications. Ahmad I, Ahmad F, Pichtel J, eds, pp 29-57. Springer, New York.

Raszka A, Ziembinska A, Wiechetek A (2009) Techniki molekularne stosowane w diagnostyce mikrobiologicznej. Środowisko 2: 101-114.

Ripka K, Denner EBM, Michaelsen A, Lubitz W, Piñar G (2006) Molecular characterization of Halobacillus strains isolated from different medieval wall paintings and building materials in Austria. Int Bioder Biodegr 58: 124-132.

Ronaghi M (2013) Pyrosequencing sheds light on DNA sequencing. Genome Res 11: 3-11.

Rölleke S, Muyzer G, Wawer C, Wanner G, Lubitz W (1996) Identification of bacteria in the biodegraded wall painting by denaturing gradient gel electrophoresis of PCR-amplified gene fragments coding for 16S rRNA. Appl Environ Microbiol 62: 2059-2065.

Rölleke S, Witte A, Wanner G, Lubitz W (1998) Medieval wall painting-a habitat for archaea: identification of archaea by denaturing gradient gel electrophoresis (DGGE) of PCR amplified gene fragments coding $16 \mathrm{~S} \mathrm{rRNA}$ in a medieval wall painting. Int Biodeter Biodegrad 41: 85-92.

Shah N, Tang H, Doak TG, Ye Y (2011) Comparing bacterial communities inferred from 16S rRNA gene sequencing and shotgun metagenomics. Pac Symp Biocomput 2011: 165-176.

Saiz-Jimenez C, Laiz L (2000) Occurrence of halotolerant and halophilic bacterial communities in deteriorated monuments. Int Bioder Biodegr 46: 319-326.

Saiz-Jimenez C, Miller AZ, Martin-Sanchez PM, Hernandez-Marine M (2012) Uncovering the origin of the black stains in Lascaux Cave in France. Environ Microb 14: 3220-3231.

Schabereiter-Gurtner C, Pinar G, Lubitz W, Rölleke S (2001) An advanced strategy to identify bacterial communities on art objects. I Microbiol Methods 45: 77-87.

Simon C, Rolf D (2011) Metagenomic analyses: past and future trends. Appl Environ Microbiol 77: 1153-1161.

Sklarz MY, Angel R, Gillor O, Soares IM (2011) Amplified rDNA restriction analysis (ARDRA) for identification and phylogenetic placement of $16 \mathrm{~S}$ rDNA clones. In Handbook of Molecular Microbial Ecology I: Metagenomics and Complementary Approaches. de Bruijn FJ, eds, pp 59-60. John Wiley \& Sons, Inc., Hoboken, New Jersey. 
Smerda J, Sedlácek I, Pácová Z, Krejcí E, Havel L (2006) Paenibacillus sepulcri sp. nov., isolated from biodeteriorated mural paintings in the Servilia tomb. Int J Sys Evol Microbiol 56: 2341-2344.

Stomeo F, Portillo MC, Gonzalez JM, Laiz L, Saiz-Jimenez C (2008) Pseudonocardia in white colonization in two caves with Paleolithic paintings. Int Biodeter Biodegr 62: 483-486.

Streit WR, Schmitz RA (2004) Metagenomics - the key to the uncultured microbes. Cur Opin Microbiol 7: 492-498.
Tatusova TA, Madden TL (1999) BLAST 2 SEQUENCES, a new tool for comparing protein and nucleotide sequences. FEMS Microbiol Lett 174: 247-250.

Tomaselli L, Lamenti G, Bosco M, Tiano P (2000) Biodiversity of photosynthetic microorganisms dwelling on stone monuments. Int Biodeter Biodegr 46: 251-258.

Więckowicz M (2009) Molekularne metody identyfikacji mikroorganizmów w złożonych ekosystemach. Post Mikrobiol 48: 67-73 (in Polish). 